\title{
Non-interest Income, Credit Risk and Bank Stability: Evidence from Vietnam
}

\author{
Van Dan Dang \& Van Cuong Dang
}

\begin{abstract}
This study examines the impact of non-interest income on bank riskiness captured by two dimensions of credit risk and bank stability. Based on a panel of Vietnamese banks during the period 2007-2017 and a dynamic approach estimated by the generalised method of moments (GMM), we find that: (1) banks more involved in non-interest income activities have less credit risk, but higher bank instability; (2) the decomposition of bank instability indicates that risk-adjusted profitability and capital buffer corresponding to risk-taking are adversely affected by non-interest income; and (3) private banks could gain more diversification benefits of credit risk reduction, while the drawback effect of income diversification on bank stability is lower for state-owned banks. Our findings exhibit the double-edged nature of the shift toward non-interest from interest income, but we have no evidence to support the notion that non-interest income drives bank stability through the transmission impact of credit risk. The study clarifies the ongoing debates about the safety and soundness of income diversification in emerging markets.
\end{abstract}

Keywords: Bank stability; Credit risk; Diversification; Non-interest income; Vietnam.

JEL Classification: G21, G32

\section{Introduction}

Non-traditional activities have increasingly contributed to bank revenue (Laeven \& Levine, 2007). These segments comprise components that generate non-interest income, such as services for fees and commissions, stakeholder activities, or foreign exchange trading. The development of such income sources has created income diversification. This trend has triggered

a Corresponding author. Department of Finance, Banking University of Ho Chi Minh City, 700000 Vietnam.Email: dandv@buh.edu.vn

b School of Public Finance, University of Economics Ho Chi Minh City, 700000 Vietnam. Email: dangcuong@ueh.edu.vn 
various strands of the literature to analyse the risk implications of income diversification before and after the global crisis of 2008, mainly looking at developed countries, such as in the US or Europe, as the deregulation initiatives in the banking industry originated in these areas during the last decades. Most of these studies draw out common downsides when shifts toward non-traditional activities lead to more standalone risks (Allen \& Santomero, 2001; De Haan \& Poghosyan, 2012; DeYoung \& Roland, 2001; Lepetit, Nys, Rous \& Tarazi, 2008a; Stiroh \& Rumble, 2006; Williams, 2016) and systemic risks (De Jonghe, 2010; De Jonghe, Diepstraten \& Schepens, 2015; Fahlenbrach, Prilmeier \& Stulz, 2012; Wagner, 2010) as a consequence of non-interest income's volatile nature. In practice, there are some reform policies suggesting restrictions on non-interest activities, a sign of concerns about the adverse effects of income diversification (International Monetary Fund, 2011).

However, the existing literature has also proposed the upsides of nontraditional activities. Li and Zhang (2013) state that at the aggregate level, there are benefits of income diversification; Abedifar, Molyneux and Tarazi (2018) give some evidence in favour of the benefits of increasing noninterest income for certain bank groups. Köhler (2014) indicates that banks will gain more stability if they establish a business model focusing on noninterest activities. Moreover, expanding into non-interest income could lead to a lower probability of bank collapse (DeYoung \& Torna, 2013).

In summary, all of the above-mentioned contrary conclusions motivate more works conducted from the view of different financial markets. Implications obtained from other previous studies in developed countries may not be effectively applied to emerging markets. Compared to developed economies, their emerging counterparts have less mature financial systems and relatively significant differences in banking systems such as market structures or regulatory frameworks. Furthermore, the banking sectors of emerging markets generally have lower non-interest income shares than those of developed markets, which have paid much earlier attention to diversifying revenue channels (Hidayat, Kakinaka \& Miyamoto, 2012). These aspects could elicit different effects on bank risk-taking behaviour during the process of diversifying into non-traditional segments. Thus, extending the current understanding by focusing on emerging markets is worthy of a comprehensive analysis.

To this end, we examine how non-interest income affects bank riskiness 
in Vietnam, a typical emerging market that has attracted little attention from academics. The banking industry in Vietnam has grown rapidly, especially after the recent economic reforms and integrations. However, the period of ineffectively controlled credit expansion has placed a massive burden on the whole system (Vo, 2018). To relieve this problem as well as to deal with extreme competition, many banks pursue the shifting of banking business to non-traditional sectors yielding non-interest income, while regulatory authorities have almost no constraints for this type of activity compared to riskier lending segments (Nguyen, Nghiem, Roca \& Sharma, 2016). Accordingly, the importance of non-interest revenue sources is overestimated in the Vietnamese banking market. Some banks have even considered it as a proxy for bank safety and soundness, failing to note the dark sides of diversification. Although the non-interest segment is on the rise and has great potential, the proportion of non-interest income in the total revenue structure is highly modest compared to that of interest income, which stems from an important channel to fuel the fast-growing economy. On a global basis, Vietnam is one of the markets whose banking industry has the lowest non-interest income share among emerging economies (see Doan, Lin \& Doong, 2018). In sum, the Vietnamese market provides a favourable context to exploit the risk characteristics associated with the diversification of bank income. Clarifying these unclear issues is also particularly necessary for other emerging countries that face similar circumstances in the move towards non-interest from interest income sources in the banking industry.

We conduct our empirical research based on annual data from 20072017. We employ the two-step generalised method of moments (GMM) estimator for the dynamic panel to explore the bank risk-taking behaviour. Bank riskiness is captured in two dimensions, namely, credit risk and bank stability. For bank stability, we decompose it to more specifically test the responses of components, including risk-adjusted profits and capitalisation. Credit risk is generally accepted as the most critical risk that a bank could face. Financial intermediation theories suggest that the mitigated asymmetric information problem due to income diversification could enhance credit quality via better supervision and monitoring, thus reducing credit risk (Abedifar et al., 2018; Boot, 2000). As shown in the first pillar of Basel II, along with operational risk and market risk, credit risk also constitutes to the overall risk of a bank. Our investigation combining both credit risk and the overall risk is to gain some specific implications. Following this approach, 
we expect to clarify whether non-interest income drives bank stability through the transmission impact of credit risks. In other words, credit risk could be a key channel through which non-interest income affects the overall risk or stability of a bank, among other risks.

Additionally, motivated by the facts that the Vietnamese banking market is dominated by state-owned banks (Batten \& Vo, 2016; Dang, 2020), while private banks are increasingly attempting to invest in non-interest segments as a result of the dominant position in lending to state-owned counterparts, the study further considers whether the impacts of non-interest income on bank riskiness differ depending on state ownership. Despite the extensive documents on the shift toward non-traditional activities, this approach has surprisingly been disregarded. It is generally accepted that as banks expand their activities to generate more income sources, they need more resources and capacity and such bank strategies differ according to ownership structure (Wang, Xie, Zhao \& Jiang, 2018). Hence, we believe that the impacts of non-interest income on bank riskiness may not be identical to all banks with different ownership groups.

The present study contributes to the body of knowledge in at least two ways. First, it sheds further light on the safety and soundness features of non-traditional banking activities in emerging markets. In particular, it empirically examines how non-interest income affects bank riskiness by a rare combination of credit risk and bank stability. For bank stability, the impact is decomposed into two dimensions capturing risk-adjusted profitability and capital buffer. Second, the study is the first to investigate the role of state ownership as a moderator in the relationship between non-interest income and bank riskiness within the context of an emerging country. Findings obtained from our tasks have provided insightful implications for regulatory agencies and bank managers themselves.

We structure the remainder of this study as follows. We move on to review related literature in Section 2. We then describe the methodology and data to perform empirical estimation in Section 3. Section 4 reports and discusses the results and then robustness checks are presented. Section 5 concludes and finally gives some policy and management implications. 


\section{Related Literature}

\subsection{Non-interest income and bank riskiness}

The shift toward non-traditional banking activities or income diversification is an important business orientation of banks, thanks to the benefits it brings about. Banks could take advantage of upsides from diversifying the sources of bank income via economies of scale, such as input shares in joint production or cross-selling activities (Jouida, 2018). From a theoretical perspective of diversification, a combination of revenue sources from various activities that have little correlation with each other will reduce bank risk. Abundant earlier research has confirmed this notion by showing that the increase of non-interest income could help banks diversify away from risk, at least partially (Gallo, Apilado \& Kolari, 1996; Kwast, 1989; Litan, 1985). Several recent studies have provided more evidence on the existence of revenue diversification benefits. Focusing on US banking holding companies, Shim (2013) claims that diversified revenue portfolios tend to reduce bank insolvency risk. The author also notes the benefits of capital savings, which significantly support banks when they face strict regulations on capital holding from regulatory agencies. Financial intermediation theories claim that competitive advantages from reduced asymmetric information problems as a result of diversification might improve credit quality through better supervision and monitoring (Boot, 2000). Also, a credit relationship after previous non-lending transactions tends to cut the probability of borrower defaults (Puri, Rocholl \& Steffen, 2011). Abedifar et al. (2018) assume that it is easier for banks to collect information and use it effectively to monitor their customers when diversifying. To verify, the authors directly survey commercial banks in the US market and find that the non-interest income from fiduciary segments reduces credit risk for medium-sized banks, especially during the pre-crisis period.

Although the academics have highlighted the benefits of non-interest income for banks, the contrary views pointing out various drawbacks are also extensively analysed in many documents. DeYoung and Roland (2001) provide solid evidence in favour of the argument that fee-based activities negatively affect the overall income volatility of banks, suggesting that income diversification could not help reducing bank riskiness. To clarify 
their conclusions, the authors have mentioned three factors. First, the noninterest segment has lower switching costs than the interest segment; thus, to maintain and develop the relationships with customers that generate non-interest income for banks, they could loosen credit policy to reinforce such relationships. This strategy may hurt the delegate-monitoring function of banks. Second, the expansion into non-interest income requires banks to invest more resources related to fixed costs. Larger operating leverage exposes banks to business risk, further placing them in danger if they could not cover fixed costs by sales revenues of the non-traditional activities (DeYoung \& Torna, 2013). Third, regulatory authorities do not impose stringent requirements to raise capital holdings against the expansion into non-interest banking activities. In this context, larger financial leverage leads to more risky investments (Demirgüç-Kunt \& Kane, 2002). The findings of DeYoung and Roland (2001) have been confirmed in many subsequent studies. Stiroh (2006) and Stiroh and Rumble (2006) discover that higher engagement in non-interest activities worsens risk-return trade-offs of banks because the volatility effects dominate any potential diversification benefits. It is also attributed to agency costs when increased complexity leads to a situation that bank managers have incentives to seek the return target rather than a simultaneous combination of both risk and return (Williams, 2016).

In line with studies on the US market, the works focusing on Europe likewise show the drawbacks of non-interest activities in increasing bank risk. Lepetit et al. (2008a) prove that small banks that are more exposed to non-interest activities incur higher default risk than other banks that mostly perceive lending as their core segment. This finding was previously shown in the study of Mercieca, Schaeck and Wolfe (2007) with a sample of small European banks, while De Jonghe (2010) indicates that banking system instability is subject to income diversification. In another study based on European banks, Lepetit et al. (2008b) find that banks are likely to ignore credit risk if they insist on exploiting non-interest revenue from borrowers, which could create a bias for loan screening and monitoring. For the German banking industry, Köhler (2014) connects to business models of banks to examine the consequences of increased exposure to non-traditional activities. While savings and cooperative banks gain more stability if they boost the non-interest income share, investment-oriented banks are observed to suffer more instability. As such, the differences in business models affect the links between income diversification and bank riskiness. 
The mixed findings on risk implications of non-interest income in prior studies are mainly based on developed economies, while the empirical evidence from emerging markets has remained relatively limited so far. Using a sample of the Indonesian banking sector, Hidayat et al. (2012) show that income diversification reduces risks for small-sized banks, while the opposite happens for large-sized banks. Focusing on Chinese banks, Li and Zhang (2013) display the increased diversification benefits of noninterest banking activities. However, the authors also emphasise that when non-interest income shares increasingly rise, the marginal diversification benefits tend to decline gradually due to the higher volatility and cyclicality of non-interest income compared to interest income, worsening the riskreturn trade-off of banks. Taking a dataset of South Asian banks, Nguyen, Skully and Perera (2012) reveal that banks tend to become more stable if they diversify their activities into non-interest segments. The authors obtain this observation for banks with higher market power. Expanding the data sample to 22 countries in Asia, Lee, Yang and Chang (2014) apply the GMM dynamic panel estimator to conclude that non-interest income reduces bank risk but does not increase bank profit on a broad sample. Taken together, our work differs from these previous studies exploring emerging markets in several dimensions, in particular: i) we focused on credit risk measured by non-performing loans and loan loss provisions; ii) we decomposed the bank stability proxy into two aspects capturing risk-adjusted profitability and capital buffer to assess disaggregate effects; iii) we study the role of state ownership as a moderator in the relationship between non-interest income and bank riskiness, while none of these prior papers analyse the similar issue, which could shed light on a highly relevant debate in emerging economies.

\subsection{The influence of state ownership}

The heterogeneity of business behaviour according to different ownership forms has been well studied in the existing literature. Abundant research relies on the agent-principal mechanism to perform its works. Deriving from the separation of ownership and management aspects, the motives of managers (agents) are based on their interests rather than those of owners (principals) (Berle \& Means, 1932). As a result, bank managers often pursue risky strategies for higher profit as a benchmark of managerial 
performance, ignoring the long-term risks. Their confidence is reinforced, given that when banks fall into financial distress, their government is always available to help (Wang et al., 2018). According to the "political view" of Sapienza (2004), the government could take advantage of their power in institutions and implement policies to fulfil its interests, such as allocating credit to investment projects essential to the economy. However, there is also an alternative view to explain the risk characteristics associated with state ownership. From the perspective of state-owned banks in transitional markets with political and financial privileges, they do not necessarily accept additional risks when they already have substantial competitive advantages (Zhou, Gao \& Zhao, 2017).

The empirical evidence on bank performance has also noticed the differences between state-owned and private banks, mostly focusing on developing or transitional economies. In general, the findings show that state-owned banks are less efficient and tend to have higher rates of nonperforming loans than their privately-owned counterparts (Altunbas, Evans \& Molyneux, 2001; La Porta, Lopez-de-Silanes \& Shleifer, 2002). In the same vein, Chen, Chou, Chang and Fang (2015) survey Chinese banks and conclude that state ownership would force banks to take more risks, implying that they are adversely affected by state control.

On a broad basis, state ownership could provide banks with ample resources to take on more risky projects and expand their businesses more easily (Zhai, Xie \& Zhang, 2017). Hence, the behaviour of all types of banks is not uniform in relation to the capacity to exploit different sources of income. Pennathur, Subrahmanyam and Vishwasrao (2012) indicate that bank ownership does matter in determining income structure. More precisely, the authors find that banks with higher levels of government ownership have more brokerage income, but less fee-based income. Besides, they also suggest the diversification benefits for government-owned banks, given their finding that moving into fee-based segments does not lead to an increase in the return volatility. The work of Elsas, Hackethal and Holzhäuser (2010) refers to agency theory to account for the phenomenon that the costs dominate diversification strategies' benefits. The inefficient resource allocation and asymmetric information may be pronounced in the case of banks with state ownership. 


\section{Methodology and Data}

\subsection{Methodology}

We apply the dynamic estimation, which is a common standard of panel data regression and a widely considered framework in many other documents, to capture the persistence of bank risk-taking behaviour (e.g., Abedifar et al., 2018; Delis and Kouretas, 2011; Lee et al., 2014; Meslier, Tacneng \& Tarazi, 2014). Accordingly, the specification is set up as follows:

Riskiness $_{i, t}=\alpha+\beta \times$ Riskiness $_{i,-1}+\gamma \times$ Non-interest $_{i, t-1}+\delta \times$ Control $_{i, t-1}+\varepsilon_{i, t}$

where subscript $i$ denotes individual banks and $t$ implies time dimension. Riskiness includes separate measures for credit risk and bank stability. Noninterest represents indicators for non-interest income of our main interest and Control is a vector of control variables allowing for bank-specific characteristics and macroeconomic environments. The lagged dependent variable is added to the right-hand side of the equation to adopt a dynamic framework. We employ the one-period lags of all independent variables to avoid the potential endogeneity. Moreover, the productivity of the banks' asset portfolio needs time to be acknowledged, or in other words the bank output is the result of earlier decisions.

For non-interest income variables, we begin with the share of net noninterest income on total operating income (NII variable) to describe the shift toward non-traditional banking activities (De Jonghe et al., 2015; Lee et al., 2014; Meslier et al., 2014; Stiroh, 2006 among many others). Besides, we also take into account the aspect of income diversification. Accordingly, two diversification indicators following the Herfindahl-Hirschman index (Doan et al., 2018; Esho, Kaufman \& Sharpe, 2005; Meslier et al., 2014; Stiroh \& Rumble, 2006) and inspired by Laeven and Levine (2007) are employed, respectively:

DiverHHI $=1$ ((noninterest income share $\left.)^{2}+(\text { interest income share })^{2}\right)$

DiverLL $=1-/$ (interest income share) - (noninterest income share) $/$

From the perspective of banks, larger values of income diversification indexes indicate higher proportions of non-interest income. Such cases also 
reveal that banks are more involved in non-traditional banking activities. This is particularly relevant in the context of the Vietnamese banking sector, where the non-interest income share is growing but still significantly lower than the interest segment.

Turning to our dependent variables, we apply traditional measures based on accounting data to display bank riskiness. The ratio of non-performing loans to total gross loans (NPL variable) highlights credit risk. Nonperforming loans consist of loans that are past due (interest or principal) for 90 days or more. For bank stability, we employ the Z-score indicator which is also well known as an inverse proxy for overall risk of financial institutions (Beck \& Laeven, 2006; Delis, Hasan \& Tsionas, 2014; Hesse \& Čihák, 2007; Houston, Lin, Lin \& Ma, 2010). The greater the Z-score is, the more soundness or less riskiness the bank has. The Z-score indicator is calculated as follows:

$$
\text { Z-score }=\frac{R O A+\text { Equity } / \text { Assets }}{\text { Standard deviation of ROA }}
$$

More precisely, we compute the standard deviation of the net return on assets (ROA) for each bank over the whole sample period and combine them with the current values of ROA and equity-to-assets ratio (see Beck \& Laeven, 2006; Hesse \& Čihák, 2007).

With respect to control variables, we first use the bank-specific determinants, including: bank size, calculated by the natural logarithm of total assets (Size variable); bank lending, proxied by the rate of loan growth (Lending variable); and liquidity position, computed by the rate of liquid asset to total assets (Liquid variable). A vast literature has looked at these factors in relation to bank riskiness (see Bitar et al., 2018; Dang, 2019a; Foos, Norden \& Weber, 2010; Ghenimi, Chaibi \& Omri, 2017; Kim \& Sohn, 2017; Lee \& Hsieh, 2013). In addition, as an alternative technique to capture the general effect of the economy on the banking industry, which is changing over time but constant for each bank (commonly expressed by year dummy), the macroeconomic factors are then integrated into the model (see Doan et al., 2018; Li \& Zhang, 2013; Meslier et al., 2014). Accordingly, we consider the annual growth rate of gross domestic product (GDP variable) and the annual inflation rate (Inflation variable). The inclusion of macroeconomic variables is appropriate for a small research sample when the choice of year 
dummy instead will reduce many degrees of freedom. Furthermore, this also helps cover the macro information related to the crisis as it is very difficult to determine the time span of crisis in Vietnam.

To investigate the influence of state ownership characteristics, we proceed with the interaction terms of the non-interest income indicators and the ownership dummy ( $S O B$ variable) which receives the value of 1 for state-owned banks and 0 otherwise. Hence, the extended specification is as follows:

$$
\begin{aligned}
& \text { Riskiness }_{i, t}= \alpha+\beta \times \text { Riskiness }_{i, t-1}+\gamma \times \text { Non-interest }_{i, t-1}+\delta \times \text { Control }_{i, t-1} \\
&+\varphi \times \text { Non-interest } \\
& i, t-1
\end{aligned}
$$

Our dynamic approach causes innate endogeneity effects. Thus, to appropriately address this problem, we apply the two-step GMM estimator, which integrates the lagged values of internal variables as instruments (Arellano \& Bover, 1995; Blundell \& Bond, 1998). The two-step standard errors are corrected according to Windmeijer (2005) procedure as we are considering a small sample. Using the GMM estimator needs some tests to validate the estimation results. Hence, we conduct the Hansen test of over-identifying restrictions to verify the overall validity of instruments and Arellano-Bond (AR) tests to assure the absence of second-order autocorrelation in the first difference residuals.

\subsection{Data}

We have manually collected Vietnamese commercial banks' data from 2007 to 2017 through annual financial reports published on each bank's website. We eliminate banks which are acquired or under special control by the state because of their different features in operation strategies and risk-taking behaviour. The final sample consists of 30 banks with 320 observations in the form of an unbalanced panel dataset. It contains four state-owned banks and 26 joint-stock banks, covering over $95 \%$ of total banking assets in Vietnam. We then winsorise all observations at the interval of $1 \%$ and $99 \%$ to mitigate the impact of outliers. Additionally, Vietnam's macroeconomic information is extracted from the World Development Indicators (WDI).

The summary statistics of the variables are shown in Table 1 . We could observe that traditional banking still provides the primary income for banks 
in the Vietnamese market, illustrated by the non-interest income share of $21.07 \%$ on average through the period under study. The market also has a significant differentiation in terms of financial structure, business efficiency and risk levels among participants, displayed by the large distances between the reported percentiles of variables.

Table 1: Summary statistics

\begin{tabular}{|c|c|c|c|c|c|c|c|c|}
\hline Variables & Definitions & Mean & $\begin{array}{l}\text { Std. } \\
\text { Dev. }\end{array}$ & $10^{\text {th }}$ & $25^{\text {th }}$ & Median & $75^{\text {th }}$ & $90^{\text {th }}$ \\
\hline \multicolumn{9}{|c|}{ Bank riskiness } \\
\hline NPL & $\begin{array}{l}\text { non-performing loans/total } \\
\text { gross loans }(\%)\end{array}$ & 2.29 & 1.47 & 0.69 & 1.31 & 2.17 & 2.72 & 3.81 \\
\hline Z-score & $\begin{array}{l}\text { measure of bank stability, } \\
\text { calculated by the Z-score } \\
\text { index }\end{array}$ & 26.13 & 13.38 & 12.21 & 15.76 & 22.33 & 34.95 & 44.22 \\
\hline \multicolumn{9}{|c|}{ Non-interest income } \\
\hline NII & $\begin{array}{l}\text { net non-interest income/ } \\
\text { total operating income }(\%)\end{array}$ & 21.07 & 19.43 & 1.69 & 10.1 & 19.06 & 29.02 & 43.77 \\
\hline DiverHHI & $\begin{array}{l}\text { revenue diversification } \\
\text { proxy following }\end{array}$ & 0.24 & 0.24 & 0.02 & 0.17 & 0.29 & 0.39 & 0.46 \\
\hline DiverLL & $\begin{array}{l}\text { Hirschmann-Herfindhal } \\
\text { index } \\
\text { diversification revenue } \\
\text { indicator following Laeven } \\
\text { and Levine (2007) }\end{array}$ & 0.35 & 0.30 & 0.01 & 0.19 & 0.36 & 0.54 & 0.72 \\
\hline \multicolumn{9}{|c|}{ Other descriptive characteristics } \\
\hline $\mathrm{SOB}$ & $\begin{array}{l}\text { dummy variable which } \\
\text { equals } 1 \text { for state-owned } \\
\text { banks and } 0 \text { otherwise }\end{array}$ & 0.14 & 0.34 & 0 & 0 & 0 & 1 & 1 \\
\hline Size & $\begin{array}{l}\text { natural logarithm of total } \\
\text { assets }\end{array}$ & 18.01 & 1.31 & 16.42 & 17.02 & 18.04 & 18.95 & 19.72 \\
\hline Lending & loan growth rate $(\%)$ & 33.56 & 23.07 & 2.73 & 13.67 & 22.69 & 42.19 & 84.58 \\
\hline Liquid & liquid asset/total assets (\%) & 18.41 & 7.96 & 8.58 & 12.89 & 17.45 & 23.55 & 28.64 \\
\hline GDP & $\begin{array}{l}\text { annual growth rate of gross } \\
\text { domestic product }(\%)\end{array}$ & 6.10 & 0.59 & 5.39 & 5.42 & 6.21 & 6.67 & 6.81 \\
\hline Inflation & annual inflation rate $(\%)$ & 8.43 & 6.36 & 3.24 & 3.52 & 7.05 & 9.09 & 18.67 \\
\hline
\end{tabular}

Notes: This table presents the summary statistics of variables based on a total of 320 observations. Bank-specific variables are obtained from financial reports and authors' calculations. Macroeconomic factors are extracted from the World Development Indicators (WDI).

Source: Author's calculation 
Table 2 presents the pairs of correlation coefficients between variables. The matrix indicates that the correlation coefficients are small, except for the non-interest income variables, which measure the same aspect. This strengthens our assumption of absent multicollinearity for the regression and the decision to choose our non-interest proxies.

Table 2: Correlation coefficients matrix

\begin{tabular}{l|lllllllllll}
\hline \multicolumn{1}{l}{ Variables } & NPL & Z-score & NII & DiverHHI & DiverLL & SOB & Size & Lending & Liquid & GDP & Inflation \\
\hline NPL & 1 & & & & & & & & & & \\
Z-score & 0.06 & 1 & & & & & & & & & \\
NII & 0.06 & 0.04 & 1 & & & & & & & & \\
DiverHHI & -0.05 & 0.00 & 0.44 & 1 & & & & & & & \\
DiverLL & -0.05 & 0.01 & 0.58 & 0.93 & 1 & & & & & & \\
SOB & 0.07 & 0.18 & 0.02 & 0.15 & 0.11 & 1 & & & & & \\
Size & 0.05 & -0.17 & 0.06 & 0.12 & 0.08 & 0.60 & 1 & & & & \\
Lending & -0.13 & -0.03 & 0.12 & 0.17 & 0.18 & -0.11 & -0.23 & 1 & & & \\
Liquid & -0.06 & -0.17 & -0.00 & 0.08 & 0.11 & -0.18 & 0.20 & -0.05 & 1 & & \\
GDP & -0.25 & -0.10 & 0.01 & 0.09 & 0.07 & 0.01 & 0.07 & 0.16 & 0.01 & 1 & \\
Inflation & 0.06 & 0.29 & -0.03 & -0.09 & -0.06 & 0.01 & -0.30 & -0.11 & -0.02 & -0.27 & 1 \\
\hline
\end{tabular}

Sources: Author's calculation

\section{Results and Discussions}

In this section, we first present the estimation results of the relationship between non-interest income and bank riskiness in the baseline model and then explore the role of state ownership characteristic in the augmented model. We further conduct robustness checks to verify the reliability of the estimation results and offer a more in-depth analysis through the decomposition of the bank stability factor. All of our estimates pass the necessary tests, including the Hansen test to verify the overall validity of the instruments and the AR tests to assure the absence of second-order autocorrelation in first-differenced errors.

\subsection{Non-interest income and bank riskiness in the baseline model}

Table 3 presents the estimation results for the function of credit risk captured by non-performing loans (columns 1-3). We observe that non-interest 
income variables exhibit negative and statistically significant coefficients at the $1 \%$ level in all regressions. The results remain identical regardless of the alternative proxies, non-interest income share or diversification indicators. Further, our finding also displays economic significance. For example, taking the regression coefficient in column 1, we could infer that an increase of one standard deviation in the non-interest income share variable (19.43) may lead to a decrease in the non-performing loan ratio by $0.33(19.43 \times 0.017)$, given the mean of credit risk indicator is 2.29 . This provides strong evidence in favour of credit risk reduction benefit as banks are more exposed to nontraditional activities. Some possible reasons may be as follows. On the one hand, the expansion into non-traditional segments could directly curtail the credit portfolio growth when banks own limited resources. The ineffective investment items may be subject to possible screening and substitution during the process of reorganisation. On the other hand, diversifying activities is beneficial for banks in obtaining important information to assess existing customers and seek potential customers to better maintain and establish lending relationships, respectively (Abedifar et al., 2018). Furthermore, financial intermediation theories claim that competitive advantages from reduced asymmetric information problems as a result of diversification might improve credit quality through better supervision and monitoring (Boot, 2000). These mechanisms thereby mitigate credit risks. From the perspective of an emerging market, our finding expands the knowledge gained from the research by Abedifar et al. (2018) in the US banking industry as they could not find overall mitigation effects on credit risk with all bank sizes.

We now move on to the analysis of bank stability. Based on the estimation results in Table 3 (columns 4-6), we find negative and significant coefficients of non-interest income at the $1 \%$ level in all regressions. These results reveal an inverse impact of non-traditional activities on bank stability; in other words, the more income diversification makes Vietnamese banks less stable. The magnitudes of the regression coefficients also provide a certain level of economic significance. For instance, based on the regression coefficient in column 5, a one standard deviation increase in the income diversification indicator (0.24) may decrease bank stability by $1.12(0.24 \times 4.687)$, given the mean of the Z-score ratio is 26.13 . This finding differs from that of Nguyen et al. (2012), who analyse the regional market portfolios of South Asian banks and claim that increasing the 
concentration on non-traditional activities could enhance the stability for the banking sector. There are several explanations for our findings. When pursuing a diversified strategy, the systems of business administration and risk management of banks become more complex as the platform of financial intermediation has changed, particularly in nascent banking markets. We also need to be aware that income from non-lending sectors is often unstable because its switching cost is much lower than that of lending activities (DeYoung \& Roland, 2001). This income volatility could damage the overall stability of banks. Also, greater exposure to the business risk is more detrimental for banks in a fast-growing financial market like Vietnam, where the market demand for non-traditional business lines is negatively affected by the heavy competition from rival financial firms and substitute products (DeYoung \& Torna, 2013).

Table 3: Baseline regression results for the function of credit risk and bank stability

\begin{tabular}{|c|c|c|c|c|c|c|}
\hline Variables & (1) NPL & (2) NPL & (3) NPL & (4) Z-score & (5) Z-score & (6) Z-score \\
\hline $\mathrm{NPL}_{\mathrm{t}-1}$ & $\begin{array}{l}0.419 * * * \\
(0.025)\end{array}$ & $\begin{array}{l}0.390 * * * \\
(0.027)\end{array}$ & $\begin{array}{l}0.397 * * * \\
(0.030)\end{array}$ & & & \\
\hline Z-score $_{\mathrm{t}-1}$ & & & & $\begin{array}{l}-0.332 * * * \\
(0.043)\end{array}$ & $\begin{array}{l}-0.272 * * * \\
(0.071)\end{array}$ & $\begin{array}{l}-0.279 * * * \\
(0.061)\end{array}$ \\
\hline $\mathrm{NII}_{\mathrm{t}-1}$ & $\begin{array}{l}-0.017 * * * \\
(0.002)\end{array}$ & & & $\begin{array}{l}-0.027 * * * \\
(0.009)\end{array}$ & & \\
\hline DiverHHI $_{\mathrm{t}-1}$ & & $\begin{array}{l}-0.964 * * * \\
(0.067)\end{array}$ & & & $\begin{array}{l}-4.687 * * * \\
(0.468)\end{array}$ & \\
\hline DiverLL $_{t-1}$ & & & $\begin{array}{l}-0.764 * * * \\
(0.064)\end{array}$ & & & $\begin{array}{l}-3.325 * * * \\
(0.455)\end{array}$ \\
\hline $\operatorname{Size}_{\mathrm{t}-1}$ & $\begin{array}{l}0.179 * * * \\
(0.046)\end{array}$ & $\begin{array}{l}0.261 * * * \\
(0.044)\end{array}$ & $\begin{array}{l}0.215 * * * \\
(0.044)\end{array}$ & $\begin{array}{l}-9.238 * * * \\
(0.648)\end{array}$ & $\begin{array}{l}-8.693 * * * \\
(0.983)\end{array}$ & $\begin{array}{l}-8.542 * * * \\
(1.015)\end{array}$ \\
\hline Lending $_{\mathrm{t}-1}$ & $\begin{array}{l}0.002 * * * \\
(0.000)\end{array}$ & $\begin{array}{l}0.002 * * * \\
(0.001)\end{array}$ & $\begin{array}{l}0.002 * * * \\
(0.001)\end{array}$ & $\begin{array}{l}-0.003 \\
(0.004)\end{array}$ & $\begin{array}{l}0.005 \\
(0.005)\end{array}$ & $\begin{array}{l}0.003 \\
(0.005)\end{array}$ \\
\hline Liquid $_{t-1}$ & $\begin{array}{l}-0.017 * * * \\
(0.004)\end{array}$ & $\begin{array}{l}-0.018 * * * \\
(0.004)\end{array}$ & $\begin{array}{l}-0.018 * * * \\
(0.005)\end{array}$ & $\begin{array}{l}-0.024 \\
(0.034)\end{array}$ & $\begin{array}{l}0.006 \\
(0.034)\end{array}$ & $\begin{array}{l}0.002 \\
(0.034)\end{array}$ \\
\hline $\mathrm{GDP}_{\mathrm{t}-1}$ & $\begin{array}{l}0.199 * * * \\
(0.026)\end{array}$ & $\begin{array}{l}0.207 * * * \\
(0.027)\end{array}$ & $\begin{array}{l}0.196 * * * \\
(0.029)\end{array}$ & $\begin{array}{l}1.630 * * * \\
(0.254)\end{array}$ & $\begin{array}{l}1.610^{* * * *} \\
(0.161)\end{array}$ & $\begin{array}{l}1.594 * * * \\
(0.124)\end{array}$ \\
\hline Inflation $_{t-1}$ & $\begin{array}{l}0.019 * * * \\
(0.007)\end{array}$ & $\begin{array}{l}0.026 * * * \\
(0.005)\end{array}$ & $\begin{array}{l}0.022 * * * \\
(0.006)\end{array}$ & $\begin{array}{l}0.132 * * * \\
(0.024)\end{array}$ & $\begin{array}{l}0.110^{* * * *} \\
(0.025)\end{array}$ & $\begin{array}{l}0.105^{* * * *} \\
(0.025)\end{array}$ \\
\hline Observations & 258 & 258 & 258 & 258 & 258 & 258 \\
\hline AR (1) test & 0.014 & 0.018 & 0.018 & 0.029 & 0.026 & 0.005 \\
\hline AR (2) test & 0.465 & 0.455 & 0.433 & 0.133 & 0.284 & 0.248 \\
\hline Hansen test & 0.345 & 0.369 & 0.385 & 0.220 & 0.271 & 0.295 \\
\hline
\end{tabular}


Notes: This table reports the regression results of equation (1). The dependent variables are NPL (columns 1-3); and Z-score (columns 4-6). The independent variables of interest are NII, DiverHHI and DiverLL. The Hansen test (p-value) is to verify the overall validity of the instruments and AR (order) test (p-value) is to assure the absence of second-order autocorrelation in first-differenced errors. $* * *$ indicates statistical significance at the $1 \%$ level. Source: Author's calculation.

Overall, we find the benefit of shifting toward non-interest income segments in terms of reducing bank credit risk. However, this benefit is offset by increased instability, which is also considered in the banks' overall risk. Our findings are similar to those in previous studies on the double-edged nature of moves into non-interest from interest income. Stiroh and Rumble (2006) point out more potential benefits gained from diversification into non-interest income, which is accompanied by drawbacks of higher return volatility. DeYoung and Roland (2001) likewise state that any decreased risk based on income diversification could be undone by other increased risks. Regarding the implication of simultaneously combining credit risk and overall stability in our empirical analysis, we have no evidence to conclude that credit risk is a key channel through which non-interest income affects banks' overall risk. Other types of risk, such as market risk or operational risk, may contribute more to this relationship.

Turning to the results of our control variables, we can observe some interesting effects of bank-level and macroeconomic factors on bank riskiness. Bank size is positively correlated with credit risk and negatively correlated with bank stability. These findings are similar to those of Kim and Sohn (2017), who claim that larger banks have more resources and incentives to engage more in risky investments. The loan growth exerts a positive effect on credit risk, implying that more lending expansion leads to decreased credit quality for banks. This result has been demonstrated in many prior studies that consider bank loan growth as a driver of credit risk due to a lack of effective monitoring in the environment of fierce competition (Dang, 2019a; Foos et al., 2010). The ratio of liquid assets induces a negative impact on credit risk, suggesting that banks maintaining higher liquidity positions tend to take less credit risk. This finding is in line with those obtained empirically by Cornetta, McNuttb, Strahanc and Tehraniand (2011) or theoretically by Lucas and McDonald (1992). They are aware that increasing bank liquidity or decreasing risky assets directly makes a safer credit portfolio. 
Concerning our macroeconomic variables, we find a positive effect of GDP growth on bank stability, while a positive correlation between economic growth and credit risk is displayed. During the economic upturns, banks generally have suitable conditions for development, but there are still threats of credit quality deterioration during this period (Curry, Fissel \& Hanweck, 2008). Besides, the inflation rate exhibits a positive correlation with credit risk. According to Lee and Hsieh (2013), a country could apply a tight monetary policy in a relatively high inflationary economy. If so, this would create difficulties for borrowers and make them incapable of repaying their loans, thus increasing the credit risk for banks. However, these issues seem not to negatively affect banks' overall stability according to our regression results, illustrated by a positive correlation between inflation and the Z-score indicator.

\subsection{The influence of state ownership characteristic in the augmented model}

To answer whether the impact of non-interest income on bank riskiness differs depending on state ownership, we continue to regress the expanded models with interaction terms. The results are reported in Table 4.

The interactions of non-interest income and state ownership are statistically significant positive in functions of both credit risk (columns 1 and 3) and bank stability (columns 4 and 5). These results suggest a presence of state ownership in moderating the revenue diversification's influences on bank riskiness. Besides, the absolute magnitudes of interaction term coefficients are smaller than those of non-interest income coefficients. Hence, these findings reveal that the benefit of reducing credit risk through nontraditional activities tends to be more pronounced at private banks than stateowned counterparts. In contrast, the drawbacks of income diversification on bank stability are mitigated for state-owned banks rather than private counterparts.

Under government control, state-owned banks often get involved in risky credit markets, such as large-scale state projects following commands on capital allocation (Sapienza, 2004). This could lead to a risky asset portfolio and in fact, the low loan quality of such a business model has been exhibited over the years in Vietnam (Dang, 2019b). Therefore, the hypothesis of information advantage for monitoring or proactively rearranging investment items is relatively weaker for state-owned banks. 
Table 4: Regression results for the moderating role of state ownership

\begin{tabular}{|c|c|c|c|c|c|c|}
\hline Variables & (1) NPL & (2) NPL & (3) NPL & (4) Z-score & (5) Z-score & (6) Z-score \\
\hline $\mathrm{NPL}_{\mathrm{t}-1}$ & $\begin{array}{l}0.428 * * * \\
(0.029)\end{array}$ & $\begin{array}{l}0.384 * * * \\
(0.028)\end{array}$ & $\begin{array}{l}0.390 * * * \\
(0.031)\end{array}$ & & & \\
\hline Z-score $_{\mathrm{t}-1}$ & & & & $\begin{array}{l}-0.303 * * * \\
(0.044)\end{array}$ & $\begin{array}{l}-0.211^{* * *} \\
(0.073)\end{array}$ & $\begin{array}{l}-0.284 * * * \\
(0.068)\end{array}$ \\
\hline $\mathrm{NII}_{\mathrm{t}-1}$ & $\begin{array}{l}-0.017 * * * \\
(0.002)\end{array}$ & & & $\begin{array}{l}-0.029 * * * \\
(0.009)\end{array}$ & & \\
\hline DiverHHI $_{t-1}$ & & $\begin{array}{l}-0.942 * * * \\
(0.115)\end{array}$ & & & $\begin{array}{l}-5.233 * * * \\
(0.554)\end{array}$ & \\
\hline $\operatorname{DiverLL}_{\mathrm{t}-1}$ & & & $\begin{array}{l}-0.768^{* * *} \\
(0.124)\end{array}$ & & & $\begin{array}{l}-3.673 * * * \\
(0.483)\end{array}$ \\
\hline $\mathrm{NII}_{\mathrm{t}-1} \times \mathrm{SOB}$ & $\begin{array}{l}0.004 * * * \\
(0.011)\end{array}$ & & & $\begin{array}{l}0.027 * * * \\
(0.047)\end{array}$ & & \\
\hline DiverHHI $_{\mathrm{t}-1 \times} \mathrm{SOB}$ & & $\begin{array}{l}0.391 \\
(2.970)\end{array}$ & & & $\begin{array}{l}4.920 * * \\
(3.328)\end{array}$ & \\
\hline $\operatorname{DiverLL}_{\mathrm{t}-1} \times \mathrm{SOB}$ & & & $\begin{array}{l}0.729 * * \\
(1.031)\end{array}$ & & & $\begin{array}{l}2.822 \\
(1.926)\end{array}$ \\
\hline Size $_{t-1}$ & $\begin{array}{l}0.250 * * * \\
(0.061)\end{array}$ & $\begin{array}{l}0.282 * * * \\
(0.063)\end{array}$ & $\begin{array}{l}0.259 * * * \\
(0.065)\end{array}$ & $\begin{array}{l}-8.504^{* * * *} \\
(0.843)\end{array}$ & $\begin{array}{l}-8.194 * * * \\
(1.016)\end{array}$ & $\begin{array}{l}-8.640 * * * \\
(0.925)\end{array}$ \\
\hline Liquid $_{t-1}$ & $\begin{array}{l}-0.021 * * * \\
(0.006)\end{array}$ & $\begin{array}{l}-0.019 \text { *** } \\
(0.004)\end{array}$ & $\begin{array}{l}-0.019 * * * \\
(0.005)\end{array}$ & $\begin{array}{l}-0.027 \\
(0.035)\end{array}$ & $\begin{array}{l}0.017 \\
(0.031)\end{array}$ & $\begin{array}{l}0.013 \\
(0.034)\end{array}$ \\
\hline $\mathrm{GDP}_{\mathrm{t}-1}$ & $\begin{array}{l}0.191 * * * \\
(0.027)\end{array}$ & $\begin{array}{l}0.204 * * * \\
(0.026)\end{array}$ & $\begin{array}{l}0.193 * * * \\
(0.031)\end{array}$ & $\begin{array}{l}1.756^{* * * *} \\
(0.288)\end{array}$ & $\begin{array}{l}1.462 * * * \\
(0.191)\end{array}$ & $\begin{array}{l}1.537 * * * \\
(0.254)\end{array}$ \\
\hline Inflation $_{t-1}$ & $\begin{array}{l}0.023 * * * \\
(0.007)\end{array}$ & $\begin{array}{l}0.026 * * * \\
(0.008)\end{array}$ & $\begin{array}{l}0.024 * * \\
(0.010)\end{array}$ & $\begin{array}{l}0.132 * * * \\
(0.029)\end{array}$ & $\begin{array}{l}0.089 * * * \\
(0.033)\end{array}$ & $\begin{array}{l}0.134 * * * \\
(0.030)\end{array}$ \\
\hline Observations & 258 & 258 & 258 & 258 & 258 & 258 \\
\hline AR (1) test & 0.012 & 0.019 & 0.020 & 0.029 & 0.036 & 0.059 \\
\hline AR (2) test & 0.474 & 0.462 & 0.451 & 0.167 & 0.424 & 0.339 \\
\hline Hansen test & 0.365 & 0.380 & 0.400 & 0.238 & 0.558 & 0.313 \\
\hline
\end{tabular}

Notes: This table reports the regression results of equation (5). The dependent variables are NPL (columns 1-3); and Z-score (columns 4-6). The independent variables of interest are NII, DiverHHI and DiverLL. The Hansen test (p-value) is to verify the overall validity of the instruments and AR (order) test (p-value) is to assure the absence of second-order autocorrelation in first-differenced errors. $* *$ and $* * *$ indicate statistical significance at the $5 \%$ and $1 \%$ levels, respectively.

Source: Author's calculation. 
As for the marginal impact on bank stability, the arguments about the abundant resources of state-owned banks may hold in our case (Zhai et al., 2017). Accordingly, these banks do not need too much more energy, time and managerial expertise to diversify activities. In contrast, these aspects pose much greater challenges for private banks, which are also subject to higher competition in non-interest segments in the market (Pennathur et al., 2012). This notion is particularly relevant to the Vietnamese context, where state-owned banks hold multiple advantages (e.g., market share, financial privileges, government support and managerial expertise) to dominate the market (Batten \& Vo, 2016; Dang, 2020). Therefore, state-owned banks are less affected by the adverse impact of non-interest activities on overall bank stability than private banks.

\subsection{Robustness checks}

While the primary regression of different independent variables of interest in subsections 4.1 and 4.2 has already ensured the robustness for our research results, we still continue to examine the sensitivity of these findings by other statistical techniques. First, we consider the rate of loan loss provisions to total gross loans ( $L L P$ variable) as an alternative proxy for credit risk. This measure is commonly applied in existing studies to reflect the possibility of loan impairments (Delis et al., 2014; Foos et al., 2010; Khan, Scheule \& $\mathrm{Wu}, 2017$; Lee \& Hsieh, 2013). The estimation results are presented in Table 5 (columns 1-3) and are consistent with the previous finding: non-interest income is negatively correlated with bank credit risk.

Second, to deepen our findings, we decide to decompose the Z-score indicator into two components to precisely determine the influenced factor, including the risk-adjusted return (RoaSD variable) and risk-based capitalisation (EquiSD variable). The former is measured by the ratio of ROA divided by the standard deviation of ROA and the latter is defined by the ratio of equity-to-assets divided by the standard deviation of ROA (see Lepetit et al., 2008a, 2008b). We regress the models with new dependent variables and the results are presented in Table 5 (columns 4-9). All regression coefficients of the decomposition variables are significantly negative, similar to the sign of the initial Z-score index. This highlights that the adverse impact of non-traditional activities on bank stability occurs in two dimensions of risk-adjusted return and bank solvency. From the 
Table 5: Robustness checks with alternative and decomposition variables

\begin{tabular}{|c|c|c|c|c|c|c|c|c|c|}
\hline Variables & $\begin{array}{l}(1) \\
\text { LLP }\end{array}$ & $\begin{array}{l}(2) \\
\text { LLP }\end{array}$ & $\begin{array}{l}(3) \\
\text { LLP }\end{array}$ & $\begin{array}{c}(4) \\
\text { RoaSD }\end{array}$ & $\begin{array}{c}(5) \\
\text { RoaSD }\end{array}$ & $\begin{array}{c}(6) \\
\text { RoaSD }\end{array}$ & $\begin{array}{c}\text { (7) } \\
\text { EquiSD }\end{array}$ & $\begin{array}{c}(8) \\
\text { EquiSD }\end{array}$ & $\begin{array}{c}\text { (9) } \\
\text { EquisD }\end{array}$ \\
\hline $\operatorname{LLP}_{\mathrm{t}-1}$ & $\begin{array}{l}0.832 * * * \\
(0.041)\end{array}$ & $\begin{array}{l}0.831 * * * \\
(0.033)\end{array}$ & $\begin{array}{l}0.837 * * * \\
(0.039)\end{array}$ & & & & & & \\
\hline RoaSD $_{t-1}$ & & & & $\begin{array}{l}0.421 * * * \\
(0.054)\end{array}$ & $\begin{array}{l}0.432 * * * \\
(0.054)\end{array}$ & $\begin{array}{l}0.429 * * * \\
(0.055)\end{array}$ & & & \\
\hline EquiSD $_{t-1}$ & & & & & & & $\begin{array}{l}-0.328 * * * \\
(0.042)\end{array}$ & $\begin{array}{l}-0.322 * * * \\
(0.068)\end{array}$ & $\begin{array}{l}-0.317 * * * \\
(0.058)\end{array}$ \\
\hline $\mathrm{NII}_{\mathrm{t}-1}$ & $\begin{array}{l}-0.021 \text { *** } \\
(0.001)\end{array}$ & & & $\begin{array}{l}-0.033 \\
(0.002)\end{array}$ & & & $\begin{array}{l}-0.033 * * * \\
(0.010)\end{array}$ & & \\
\hline DiverHHI $_{t-1}$ & & $\begin{array}{l}-0.177 \\
(0.050)\end{array}$ & & & $\begin{array}{l}-0.412 * * * \\
(0.144)\end{array}$ & & & $\begin{array}{l}-6.010^{* * * *} \\
(1.044)\end{array}$ & \\
\hline $\operatorname{DiverLL}_{\mathrm{t}-1}$ & & & $\begin{array}{l}-0.142 * * * \\
(0.041)\end{array}$ & & & $\begin{array}{l}-0.233 * * \\
(0.105)\end{array}$ & & & $\begin{array}{l}-3.555 * * * \\
(0.324)\end{array}$ \\
\hline $\mathrm{NII}_{\mathrm{t}-1} \times \mathrm{SOB}$ & $\begin{array}{l}0.011 * * * \\
(0.004)\end{array}$ & & & $\begin{array}{l}0.037 * * \\
(0.015)\end{array}$ & & & $\begin{array}{l}0.011 * * * \\
(0.045)\end{array}$ & & \\
\hline DiverHHI $_{t-1} \times \mathrm{SOB}$ & & $\begin{array}{l}0.091 \\
(0.553)\end{array}$ & & & $\begin{array}{l}0.132 * * * \\
(0.810)\end{array}$ & & & $\begin{array}{l}0.606^{*} \\
(0.989)\end{array}$ & \\
\hline DiverLL $_{\mathrm{t}-1} \times \mathrm{SOB}$ & & & $\begin{array}{l}0.025 \\
(0.233)\end{array}$ & & & $\begin{array}{l}0.020 * * * \\
(0.731)\end{array}$ & & & $\begin{array}{l}1.274 \\
(1.065)\end{array}$ \\
\hline Control $_{t-1}$ & Yes & Yes & Yes & Yes & Yes & Yes & Yes & Yes & Yes \\
\hline Observations & 258 & 258 & 258 & 258 & 258 & 258 & 258 & 258 & 258 \\
\hline AR (1) test & 0.000 & 0.000 & 0.000 & 0.001 & 0.001 & 0.001 & 0.011 & 0.086 & 0.049 \\
\hline $\mathrm{AR}(2)$ test & 0.546 & 0.535 & 0.469 & 0.186 & 0.234 & 0.194 & 0.277 & 0.754 & 0.514 \\
\hline Hansen test & 0.513 & 0.517 & 0.569 & 0.367 & 0.409 & 0.336 & 0.344 & 0.407 & 0.314 \\
\hline
\end{tabular}

This table reports the regression results of equation (5). The dependent variables are LLP (columns 1-3) and two decomposition ratios including RoaSD (columns 4-6) and EquiSD (columns 7-9). The independent variables of interest are NII, DiverHHI and DiverLL. The Hansen test (p-value) is to verify the overall validity of the instruments and AR (order) test (p-value) is to assure the absence of second-order autocorrelation in first-differenced errors. $*, * *$ and $* * *$ indicate statistical significance at the $10 \%, 5 \%$ and $1 \%$ levels, respectively.

Source: Author's calculation.

perspective of an emerging country, the detailed analysis strongly supports Nguyen's (2012) arguments that a higher share of non-interest income worsens risk-adjusted bank returns. We could also observe that the capital buffer corresponding to the banks' exposure to risk is negatively affected by the fluctuations in financial performance illustrated by the increased noninterest income. One clear mechanism is that regulators do not require banks to hold capital against non-traditional activities. Thus, massive financial 
Table 6: Robustness checks with winsorised variables at 5\% and 95\%

\begin{tabular}{|c|c|c|c|c|c|c|}
\hline Variables & $\begin{array}{l}\text { (1) } \\
\text { NPL }\end{array}$ & $\begin{array}{l}(2) \\
\text { NPL }\end{array}$ & $\begin{array}{l}(3) \\
\text { NPL }\end{array}$ & $\begin{array}{c}\text { (4) } \\
\text { Z-score }\end{array}$ & $\begin{array}{c}\text { (5) } \\
\text { Z-score }\end{array}$ & $\begin{array}{c}\text { (6) } \\
\text { Z-score }\end{array}$ \\
\hline $\mathrm{NPL}_{\mathrm{t}-1}$ & $\begin{array}{l}0.537 * * * \\
(0.047)\end{array}$ & $\begin{array}{l}0.506 * * * \\
(0.044)\end{array}$ & $\begin{array}{l}0.500 * * * \\
(0.040)\end{array}$ & & & \\
\hline Z-score $_{\mathrm{t}-1}$ & & & & $\begin{array}{l}0.271 * * * \\
(0.059)\end{array}$ & $\begin{array}{l}0.293 * * * \\
(0.061)\end{array}$ & $\begin{array}{l}0.280 * * * \\
(0.058)\end{array}$ \\
\hline $\mathrm{NII}_{\mathrm{t}-1}$ & $\begin{array}{l}-0.015 * * * \\
(0.002)\end{array}$ & & & $\begin{array}{l}-0.055^{* * *} \\
(0.007)\end{array}$ & & \\
\hline DiverHHI $_{t-1}$ & & $\begin{array}{l}-1.176^{* * *} \\
(0.200)\end{array}$ & & & $\begin{array}{l}-7.031 * * * \\
(1.078)\end{array}$ & \\
\hline DiverLL $_{\mathrm{t}-1}$ & & & $\begin{array}{l}-0.637 * * * \\
(0.130)\end{array}$ & & & $\begin{array}{l}-3.841^{* * *} \\
(0.521)\end{array}$ \\
\hline $\mathrm{NII}_{\mathrm{t}-1} \times \mathrm{SOB}$ & $\begin{array}{l}0.014 * * * \\
(0.011)\end{array}$ & & & $\begin{array}{l}0.052 * * \\
(0.083)\end{array}$ & & \\
\hline DiverHHI $_{t-1} \times \mathrm{SOB}$ & & $\begin{array}{l}1.102 * * * \\
(0.933)\end{array}$ & & & $\begin{array}{l}1.527 * \\
(0.640)\end{array}$ & \\
\hline $\operatorname{DiverLL}_{\mathrm{t}-1} \times \mathrm{SOB}$ & & & $\begin{array}{l}0.939 * * * \\
(0.676)\end{array}$ & & & $\begin{array}{l}1.716^{*} \\
(0.325)\end{array}$ \\
\hline Control $_{t-1}$ & Yes & Yes & Yes & Yes & Yes & Yes \\
\hline Observations & 258 & 258 & 258 & 258 & 258 & 258 \\
\hline AR (1) test & 0.001 & 0.002 & 0.002 & 0.051 & 0.036 & 0.036 \\
\hline $\mathrm{AR}(2)$ test & 0.722 & 0.689 & 0.682 & 0.603 & 0.821 & 0.798 \\
\hline Hansen test & 0.412 & 0.453 & 0.423 & 0.295 & 0.377 & 0.315 \\
\hline
\end{tabular}

Notes: This table reports the regression results of equation (5). The dependent variables are NPL (columns 1-3); and Z-score (columns 4-6). The independent variables of interest are NII, DiverHHI and DiverLL. The Hansen test (p-value) is to verify the overall validity of the instruments and AR (order) test (p-value) is to assure the absence of second-order autocorrelation in first-differenced errors. $*, * *$ and $* * *$ indicate statistical significance at the $10 \%, 5 \%$ and $1 \%$ levels, respectively.

Source: Author's calculation.

leverage could be abused. This finding extends the study of Köhler (2014) in the German market with no effect on bank solvency found.

Third, regarding data processing, we further winsorise our variables in the interval of $5 \%$ and $95 \%$ and then repeat all regressions as performed previously. Our checks in Tables 6 and 7 indicate that the previous patterns remain unchanged, thus strongly confirming our findings. We include full sets of all control variables while rerunning regressions, but do not report them here for brevity. They are always available upon request. 
Table 7: Robustness checks with alternative and decomposition variables winsorised at $5 \%$ and $95 \%$

\begin{tabular}{|c|c|c|c|c|c|c|c|c|c|}
\hline Variables & $\stackrel{(1)}{\text { LLP }}$ & $\stackrel{(2)}{\text { LLP }}$ & $\begin{array}{l}\text { (3) } \\
\text { LLP }\end{array}$ & $\begin{array}{c}(4) \\
\text { RoaSD }\end{array}$ & $\begin{array}{c}(5) \\
\text { RoaSD }\end{array}$ & $\begin{array}{c}(6) \\
\text { RoaSD }\end{array}$ & $\begin{array}{c}\text { (7) } \\
\text { EquiSD }\end{array}$ & $\begin{array}{c}(8) \\
\text { EquiSD }\end{array}$ & $\begin{array}{c}\text { (9) } \\
\text { EquiSD }\end{array}$ \\
\hline $\operatorname{LLP}_{t-1}$ & $\begin{array}{l}0.870 * * * \\
(0.036)\end{array}$ & $\begin{array}{l}0.854 * * * \\
(0.042)\end{array}$ & $\begin{array}{l}0.861 * * * \\
(0.039)\end{array}$ & & & & & & \\
\hline $\operatorname{RoaSD}_{\mathrm{t}-1}$ & & & & $\begin{array}{l}0.273 * * * \\
(0.046)\end{array}$ & $\begin{array}{l}0.244 * * * \\
(0.047)\end{array}$ & $\begin{array}{l}0.257 * * * \\
(0.044)\end{array}$ & & & \\
\hline EquiSD $_{\mathrm{t}-1}$ & & & & & & & $\begin{array}{l}0.197 * * * \\
(0.037)\end{array}$ & $\begin{array}{l}0.193 * * * * \\
(0.035)\end{array}$ & $\begin{array}{l}0.198 * * * \\
(0.038)\end{array}$ \\
\hline $\mathrm{NII}_{\mathrm{t}-1}$ & $\begin{array}{l}-0.022 * * * \\
(0.001)\end{array}$ & & & $\begin{array}{l}-0.004 * \\
(0.002)\end{array}$ & & & $\begin{array}{l}-0.038 * * * \\
(0.005)\end{array}$ & & \\
\hline DiverHHI $_{t-1}$ & & $\begin{array}{l}-0.094 \\
(0.108)\end{array}$ & & & $\begin{array}{l}-0.451 * * * \\
(0.192)\end{array}$ & & & $\begin{array}{l}-6.654 * * * \\
(0.882)\end{array}$ & \\
\hline DiverLL $_{t-1}$ & & & $\begin{array}{l}-0.108 * * \\
(0.075)\end{array}$ & & & $\begin{array}{l}-0.224 * \\
(0.125)\end{array}$ & & & $\begin{array}{l}-3.262 * * * \\
(0.463)\end{array}$ \\
\hline $\mathrm{NII}_{\mathrm{t}-1} \times \mathrm{SOB}$ & $\begin{array}{l}0.017 * * * \\
(0.005)\end{array}$ & & & $\begin{array}{l}0.002 \\
(0.009)\end{array}$ & & & $\begin{array}{l}0.114 * \\
(0.064)\end{array}$ & & \\
\hline DiverHHI $_{t-1} \times$ SOB & & $\begin{array}{l}1.427 * * \\
(0.646)\end{array}$ & & & $\begin{array}{l}2.609 \\
(2.558)\end{array}$ & & & $\begin{array}{l}2.130 * * * \\
(0.542)\end{array}$ & \\
\hline DiverLL $_{\mathrm{t}-1} \times \mathrm{SOB}$ & & & $\begin{array}{l}0.073 * * \\
(0.385)\end{array}$ & & & $\begin{array}{l}0.845 \\
(1.424)\end{array}$ & & & $\begin{array}{l}2.500 * * \\
(0.269)\end{array}$ \\
\hline Control $_{\mathrm{t}-1}$ & Yes & Yes & Yes & Yes & Yes & Yes & Yes & Yes & Yes \\
\hline Observations & 258 & 258 & 258 & 258 & 258 & 258 & 258 & 258 & 258 \\
\hline $\mathrm{AR}$ (1) test & 0.000 & 0.000 & 0.000 & 0.002 & 0.003 & 0.003 & 0.093 & 0.093 & 0.081 \\
\hline AR (2) test & 0.806 & 0.829 & 0.796 & 0.111 & 0.159 & 0.125 & 0.927 & 0.801 & 0.879 \\
\hline Hansen test & 0.331 & 0.226 & 0.292 & 0.516 & 0.439 & 0.425 & 0.350 & 0.409 & 0.395 \\
\hline
\end{tabular}

Notes: This table reports the regression results of equation (5). The dependent variables are $L L P$ (columns 1-3) and two decomposition ratios including RoaSD (columns 4-6) and EquiSD (columns 7-9). The independent variables of interest are NII, DiverHHI and DiverLL. The Hansen test (p-value) is to verify the overall validity of the instruments and AR (order) test ( $\mathrm{p}$-value) is to assure the absence of second-order autocorrelation in first-differenced errors. $*, * *$ and $* * *$ indicate statistical significance at the $10 \%, 5 \%$ and $1 \%$ levels, respectively.

Source: Author's calculation.

\section{Conclusion}

This study investigates the impact of non-interest income on bank riskiness in Vietnam, a typical emerging country that offers an ideal context to study this relationship. After a period of ineffectively rapid credit growth and fierce competition in the credit segment, regulatory agencies and bank managers 
in the Vietnamese market seem to favour non-traditional activities to reduce bank riskiness. However, the streams of literature simultaneously highlight the benefits and drawbacks of non-traditional activities with mixed findings, mostly based on developed markets, while very little attention has been paid to emerging economies like Vietnam. Under such scenarios, our empirical research emerges with some significant results.

First, the diversification into non-traditional activities reduces credit risk, while inducing adverse effects on bank stability. Through the decomposition technique of bank stability, we also observe the impact of income diversification on both dimensions of bank profitability and capitalisation. These findings are consistent with prior studies, showing the double-edged nature of the concentration on the non-interest segments (DeYoung \& Roland, 2001; Stiroh \& Rumble, 2006). Moreover, the findings provide evidence supporting a difference between two types of bank ownership, state-owned and private, in the association between income diversification and bank riskiness captured by both credit risk and bank stability. More precisely, state ownership mitigates the diversification benefits of credit risk reduction while performing a better role to reduce the drawback of income diversification on bank stability. Our conclusions are robust across different sets of measures and alternative data estimation methods.

Based on the findings, this study has some implications. Regulators and market participants should be aware of the potentially decreased or increased bank riskiness when expanding into non-traditional activities. From the perspective of credit risk reduction, bank efficiency is proven, but the pattern may be reversed for the overall risk of banks. A trade-off between these two targets needs to be carefully considered. Besides, given our finding that state-owned and private banks react differently to the adjustment of noninterest income, we suggest considering bank ownership when analysing the effect of income diversification on bank riskiness. A policy framework that distinguishes different ownership structures should be developed to ensure that banks could appropriately enhance the income diversification benefits and mitigate the potential drawbacks.

\section{References}

Abedifar, P., Molyneux, P. \& Tarazi, A. (2018). Non-interest income and bank lending. Journal of Banking \& Finance, 87, 411-426. http://dx.doi. 
org/10.1016/j.jbankfin.2017.11.003

Allen, F. \& Santomero, A.M. (2001). What do financial intermediaries do? Journal of Banking \& Finance, 25(2), 271-294. https://doi.org/10.1016/ S0378-4266(99)00129-6

Altunbas, Y., Evans, L. \& Molyneux, P. (2001). Bank ownership and efficiency. Journal of Money, Credit and Banking, 33, 926-954.

Arellano, M. \& Bover, O. (1995). Another look at the instrumental variable estimation of error-components models. Journal of Econometrics, 68(1), 29-51. https://doi.org/10.1016/0304-4076(94)01642-D

Batten, J.A. \& Vo, X.V. (2016). Bank risk shifting and diversification in an emerging market. Risk Management, 18(4), 217-235. https://doi. org/10.1057/s41283-016-0008-2

Beck, T. \& Laeven, L. (2006). Resolution of failed banks by deposit insurers: Cross-country evidence. Policy Research Working Paper 3920, World Bank.

Berle, A.A. \& Means, G.C. (1932). The Modern Corporation and Private Property. New York: MacMillan.

Bitar, M., Pukthuanthong, K. \& Walker, T. (2018). The effect of capital ratios on the risk, efficiency and profitability of banks: Evidence from OECD countries. Journal of International Financial Markets, Institutions and Money, 53, 227-262. https://doi.org/10.1016/j.intfin.2017.12.002

Blundell, R. \& Bond, S. (1998). Initial conditions and moment restrictions in dynamic panel data models. Journal of Econometrics, 87(1), 115-143. https://doi.org/10.1016/S0304-4076(98)00009-8

Boot, A.W.A. (2000). Relationship banking: what do we know?. Journal of Financial Intermediation, 9(1), 7-25. https://doi.org/10.1006/ jfin. 2000.0282

Chen, T-.H., Chou, H-.H, Chang, Y. \& Fang, H. (2015). The effect of excess lending on bank liquidity: Evidence from China. International Review of Economics \& Finance, 36, 54-68. https://doi.org/10.1016/j. iref.2014.11.007

Cornetta, M.M., McNuttb, J.J., Strahanc, P.E. \& Tehraniand, H. (2011). Liquidity risk management and credit supply in the financial crisis. Journal of Financial Economics, 101(2), 297-312. https://doi. org/10.1016/j.jfineco.2011.03.001

Curry, T.J., Fissel, G.S. \& Hanweck, G.A. (2008). Is there cyclical bias in bank holdings company risk ratings? Journal of Banking \& Finance, 
32(7), 1297-1309. http://dx.doi.org/10.1016/j.jbankfin.2007.11.009

Dang, V. D. (2019a). The effects of loan growth on bank performance:

Evidence from Vietnam. Management Science Letters, 9, 899-910. https://doi.org/ 10.5267/j.msl.2019.2.012

Dang, V. D. (2019b). The risk-return trade-off of liquidity positions: evidence from Vietnamese banking system. International Journal of Monetary Economics and Finance, 12(5), 390-406. https://doi.org/10.1504/ IJMEF.2019.102954

Dang, V. D. (2020). Do non-traditional banking activities reduce bank liquidity creation? Evidence from Vietnam. Research in International Business and Finance, 101257. https://doi.org/10.1016/j. ribaf.2020.101257

De Haan, J. \& Poghosyan, T. (2012). Bank size, market concentration and bank earnings volatility in the US. Journal of International Financial Markets, Institutions and Money, 22(1), 35-54. https://doi.org/10.1016/j. intfin.2011.07.002

De Jonghe, O. (2010). Back to the basics in banking? A micro-analysis of banking system stability. Journal of Financial Intermediation, 19(3), 387-417. https://doi.org/10.1016/j.jfi.2009.04.001

De Jonghe, O., Diepstraten, M. \& Schepens, G. (2015). Banks' size, scope and systemic risk: What role for conflicts of interest? Journal of Banking \& Finance, 61(S1), S3-S13. https://doi.org/10.1016/j. jbankfin.2014.12.024

Delis, M.D. \& Kouretas, G.P. (2011). Interest rates and bank risk-taking. Journal of Banking \& Finance, 35, 840-855. https://doi.org/10.1016/j. jbankfin.2010.09.032

Delis, M.D., Hasan, I. \& Tsionas, E.G. (2014). The risk of financial intermediaries. Journal of Banking \& Finance, 44, 1-12. https://doi. org/10.1016/j.jbankfin.2014.03.024

Demirgüç-Kunt, A. \& Kane, E.J. (2002). Deposit insurance around the globe: Where does it work? Journal of Economic Perspectives, 16, 175-195. https://doi.org/10.1257/0895330027319

DeYoung, R. \& Roland, K.P. (2001). Product mix and earnings volatility at commercial banks: Evidence from a degree of total leverage model. Journal of Financial Intermediation, 10(1), 54-84. https://doi. org/10.1006/jfin.2000.0305

DeYoung, R. \& Torna, G. (2013). Nontraditional banking activities and bank 
failures during the financial crisis. Journal of Financial Intermediation, 22(3), 397-421. https://doi.org/10.1016/j.jfi.2013.01.001

Doan, A-.T., Lin, K-.L. \& Doong, S-.C. (2018). What drives bank efficiency? The interaction of bank income diversification and ownership. International Review of Economics and Finance, 55, 203-219. http:// dx.doi.org/10.1016/j.iref.2017.07.019

Elsas, R., Hackethal, A. \& Holzhäuser, M. (2010). The anatomy of bank diversification. Journal of Banking \& Finance, 34(6), 1274-1287. https:// doi.org/10.1016/j.jbankfin.2009.11.024

Esho, N., Kaufman, P. \& Sharpe, I. (2005). Diversification, fee income and credit union risk. Journal of Financial Services Research, 27(3), 259-281. https://doi.org/10.1007/s10693-005-1804-0

Fahlenbrach, R., Prilmeier, R. \& Stulz, R.M. (2012). This time is the same: Using bank performance in 1998 to explain bank performance during the recent financial crisis. Journal of Finance, 67(6), 2139-2185. https://doi. org/10.1111/j.1540-6261.2012.01783.x

Foos, D., Norden, L. \& Weber, M. (2010). Loan growth and riskiness of banks. Journal of Banking \& Finance, 34(12), 2929-2240. https://doi. org/10.1016/j.jbankfin.2010.06.007

Gallo, J.G., Apilado, V.P. \& Kolari, J.W. (1996). Commercial bank mutual fund activities: Implications for bank risk and profitability. Journal of Banking \& Finance, 20(10), 1775-1791. https://doi.org/10.1016/S03784266(96)00024-6

Ghenimi, A., Chaibi, H. \& Omri, M.A.B. (2017). The effects of liquidity risk and credit risk on bank stability: Evidence from the MENA region. Borsa Istanbul Review, 17(4), 238-248. http://dx.doi.org/10.1016/j. bir.2017.05.002

Gonzalez, F. (2005). Bank regulation and risk-taking incentives: An international comparison of bank risk. Journal of Banking \& Finance, 29(5), 1153-1184. https://doi.org/10.1016/j.jbankfin.2004.05.029

Hesse, H. \& Čihák, M. (2007). Cooperative banks and financial stability. IMF Working Paper 07/2, International Monetary Fund.

Hidayat, W.Y., Kakinaka, M. \& Miyamoto, H. (2012). Bank risk and non-interest income activities in the Indonesian banking industry. Journal of Asian Economics, 23, 335-343. http://dx.doi.org/10.1016/j. asieco.2012.03.008

Houston, J.F., Lin, C., Lin, P. \& Ma, Y. (2010). Creditor rights, information 
sharing and bank risk taking. Journal of Financial Economics, 96(3), 485-512. https://doi.org/10.1016/j.jfineco.2010.02.008

International Monetary Fund. (2011). Making banks safer: Can Volcker and Vickers do it? IMF Working Paper No. 11/236.

Jouida, S. (2018). Diversification, capital structure and profitability: A panel VAR approach. Research in International Business and Finance, 45, 243-256. http://dx.doi.org/10.1016/j.ribaf.2017.07.155

Khan, M.S., Scheule, H. \& Wu, E. (2017). Funding liquidity and bank risk taking. Journal of Banking \& Finance, 82, 203-216. https://doi. org/10.1016/j.jbankfin.2016.09.005

Kim, D. \& Sohn, W. (2017). The effect of bank capital on lending: Does liquidity matter? Journal of Banking \& Finance, 77, 95-107. http:// dx.doi.org/10.1016/j.jbankfin.2017.01.011

Köhler, M. (2014). Does non-interest income make banks more risky? Retail- versus investment-oriented banks. Review of Financial Economics, 23(4), 182-193. http://dx.doi.org/10.1016/j.rfe.2014.08.001

Kwast, M.L. (1989). The impact of underwriting and dealing on bank returns and risks. Journal of Banking \& Finance, 13(1), 101-125. https://doi. org/10.1016/0378-4266(89)90022-8

La Porta, R., Lopez-de-Silanes, F. \& Shleifer, A. (2002). Government ownership of banks. Journal of Finance, 57(1), 265-302. https://doi. org/10.1111/1540-6261.00422

Laeven, L. \& Levine, R. (2007). Is there a diversification discount in financial conglomerates? Journal of Financial Economics, 85(2), 331367. https://doi.org/10.1016/j.jfineco.2005.06.001

Lee, C-.C. \& Hsieh., M-.F. (2013). The impact of capital on profitability and risk in Asian banking. Journal of International Money and Finance, 32, 251-281. https://doi.org/10.1016/j.jimonfin.2012.04.013

Lee, C-.C., Yang, S-.J. \& Chang, C-.H. (2014). Non-interest income, profitability and risk in banking industry: A cross-country analysis. North American Journal of Economics and Finance, 27, 48-67. http://dx.doi. org/10.1016/j.najef.2013.11.002

Lepetit, L., Nys, E., Rous, P. \& Tarazi, A. (2008a). Bank income structure and risk: An empirical analysis of European banks. Journal of Banking \& Finance, 32(8), 1452-1467. https://doi.org/10.1016/j. jbankfin.2007.12.002 
Lepetit, L., Nys, E., Rous, P. \& Tarazi, A. (2008b). The expansion of services in European banking: Implications for loan pricing and interest margins. Journal of Banking \& Finance, 32(11), 2325-2335. https://doi. org/10.1016/j.jbankfin.2007.09.025

Li, L. \& Zhang, Y. (2013). Are there diversification benefits of increasing noninterest income in the Chinese banking industry? Journal of Empirical Finance, 24, 151-165. http://dx.doi.org/10.1016/j. jempfin.2013.10.004

Litan, R.E. (1985). Evaluating and controlling the risks of financial product deregulation. Yale Journal on Regulation, 3, 1-52.

Lucas, D.J. \& McDonald, R.L. (1992). Bank financing and investment decisions with asymmetric information about loan quality. The RAND Journal of Economics, 23(1), 86-105. https://doi.org/10.2307/2555434

Mercieca, S., Schaeck, K. \& Wolfe, S. (2007). Small European banks: benefits from diversification? Journal of Banking \& Finance, 31(7), 1975-1998. https://doi.org/10.1016/j.jbankfin.2007.01.004

Meslier, C., Tacneng, R.C. \& Tarazi, A. (2014). Is bank income diversification beneficial? Evidence from an emerging economy. Journal of International Financial Markets, Institutions and Money, 31, 97-126. http://dx.doi.org/10.1016/j.intfin.2014.03.007

Nguyen, J. (2012). The relationship between net interest margin and non-interest income using a system estimation approach. Journal of Banking \& Finance, 36(9), 2429-2437. https://doi.org/10.1016/j. jbankfin.2012.04.017

Nguyen, M., Skully, M. \& Perera, S. (2012). Market power, revenue diversification and bank stability: Evidence from selected South Asian countries. Journal of International Financial Markets, Institutions and Money, 22, 897-912. https://doi.org/10.1016/j.intfin.2012.05.008

Nguyen, T.P.T., Nghiem, S.H., Roca, E. \& Sharma, P. (2016). Bank reforms and efficiency in Vietnamese banks: Evidence based on SFA and DEA. Applied Economics, 48(30), 2822-2835. https://doi.org/10.1080/000368 46.2015.1130788

Pennathur, A.K., Subrahmanyam, V. \& Vishwasrao, S. (2012). Income diversification and risk: Does ownership matter? An empirical examination of Indian banks. Journal of Banking \& Finance, 36(8), 2203-2215. https://doi.org/10.1016/j.jbankfin.2012.03.021

Puri, M., Rocholl, J. \& Steffen, S. (2011). On the importance of prior 
relationships in bank loans to retail customers, ECB Working Paper No. 1395. Retrieved from https://ssrn.com/abstract $=1949786$

Sapienza, P. (2004). The effects of government ownership on bank lending. Journal of Financial Economics, 72, 357-384. https://doi.org/10.1016/j. jfineco.2002.10.002

Shim, J. (2013). Bank capital buffer and portfolio risk: The influence of business cycle and revenue diversification. Journal of Banking \& Finance, 37, 761-772. http://dx.doi.org/10.1016/j.jbankfin.2012.10.002

Stiroh, K. \& Rumble, A. (2006). The dark side of diversification: The case of US financial holding companies. Journal of Banking \& Finance, 30(8), 2131-2161. https://doi.org/10.1016/j.jbankfin.2005.04.030

Stiroh, K.J. (2006). New evidence on the determinants of bank risk. Journal of Financial Service Research, 30, 237-263. https://doi.org/10.1007/ s10693-006-0418-5

Vo, X.V. (2018). Bank lending behavior in emerging markets. Finance Research Letters, 27, 129-134. https://doi.org/10.1016/j.frl.2018.02.011 Wagner, W. (2010). Diversification at financial institutions and systemic crises. Journal of Financial Intermediation, 19(3), 373-386. https://doi. org/10.1016/j.jfi.2009.07.002

Wang, G.J., Xie, C., Zhao, L. \& Jiang, Z-.Q. (2018). Volatility connectedness in the Chinese banking system: Do state-owned commercial banks contribute more? Journal of International Financial Markets, Institutions and Money, 57, 205-230. https://doi.org/10.1016/j.intfin.2018.07.008

Williams, B. (2016). The impact of non-interest income on bank risk in Australia. Journal of Banking \& Finance, 73, 16-37. https://doi. org/10.1016/j.jbankfin.2016.07.019

Windmeijer, F. (2005). A finite sample correction for the variance of linear efficient two-step GMM estimators. Journal of Econometrics, 126(1), 25-51. https://doi.org/10.1016/j.jeconom.2004.02.005

Zhai, S., Xie, L. \& Zhang, S. (2017). Bank connections and corporate risktaking: Evidence from China. Asia-Pacific Journal of Accounting \& Economics, 24(1-2), 183-194. https://doi.org/10.1080/16081625.2015 .1105831

Zhou, K.Z., Gao, G.Y. \& Zhao, H. (2017). State ownership and firm innovation in China: An integrated view of institutional and efficiency logics. Administrative Science Quarterly, 62(2), 375-404. https://doi. org/10.1177/0001839216674457 